\title{
The Reality of Knowledge Sharing Methods (Techniques) among Employees of Saudi Arabia's Public Sector (Ministry of Education: Case Study)
}

Hesah Muneer Z. Albogami* and Mona Dakhel Alsareehi

Department of Informatics, King Abdulaziz University, Jeddah - Kingdom of Saudi Arabia; albogami55@gmail.com, malsuraihi@kau.edu.sa

\begin{abstract}
Objectives: The study aimed to identify the reality of knowledge sharing among employees of Saudi Arabia's government/ public sector and the most prominent methods (techniques) of sharing their knowledge as well as their preferred methods of knowledge sharing. Methods/Statistical Analysis: The Ministry of Education was selected as a population of study using the case study method. A random sample of (400) individuals distributed to both male and female employees in universities using the questionnaire as a main tool for the study. Findings: The main results of the study were that the preferred methods among sample individuals to share knowledge are (help colleagues /workmates in case of need, participation in discussions to find solutions, use modern methods of communication with colleagues, education and training, moral encouragement, formation of interest groups, the use of a database to document knowledge and the use of traditional methods to document knowledge). Application/Improvements: The methods used for among sample individuals for knowledge sharing have been as follows (provide help and assistance in case of need, training by expert employees, hands-on training, participation in work discussions, the use of databases and the use of modern means of communication).
\end{abstract}

Keywords: Explicit and Implicit Knowledge, Government/Public Sector Employees, Knowledge Sharing, Knowledge Sharing Methods

\section{Introduction}

Knowledge is the most important and fundamental requirement that organizations seek to acquire to achieve a competitive advantage. Many organizations are keen to activate the concepts and contents of knowledge management as an organizational management concept that achieves this objective. It is an administrative process that has inputs and outputs and operates within a specific external environment that influences its interactions and is divided into consecutive and complicated multiple steps such as knowledge creation, collection, storage, distribution and utilization. The aim of which is to share knowledge in the most efficient manner in order to maximize the value of the organization 1 .

${ }^{*}$ Author for correspondence
Nanado also stated that knowledge sharing is the result of the interaction between the individual and the organization on the one hand and the integration between explicit knowledge and implicit knowledge on the other. Also, to discover, develop, use, receive and absorb knowledge from within or outside the organization through an appropriate management process to meet current and future needs. It has been defined by Aktayas as the process of attracting, storing, sharing and using knowledge ${ }^{2}$.

$\mathrm{In}^{3}$ stated that it is the process of identification, collection, storage, retrieval, dissemination and application of explicit and implicit intellectual capital for the better benefit of individuals, the market and society. It 
is the utilization of the accumulated wisdom to increase responsiveness and innovation.

In his definition of knowledge management, Al-Kubaisi stated that knowledge management at the level of organizations and communities was intended to carry out the following steps and functions: knowledge Acquisition - Knowledge Distribution and Communication - Knowledge Interpretation ${ }^{4}$.

As the process of knowledge sharing is the subject of the study, the definition of knowledge management states that it is a process whereby accumulated experience is accumulated in the minds of employees in preparation for sharing with others.

The researcher believes that this definition is more closely related to the role of knowledge management or its definition as a transfer of the accumulated experience among old employees (experts in nature of work) to the fresh employees through experiences sharing with these experts and working with new staff and employees despite the great importance of this attitude followed by this study and based on what the researchers presented in the definition of knowledge management, so knowledge sharing can be defined as: processes, procedures and methods used by experts of old employees to share their experiences with new staff and employees in the organization.

\section{Previous Studies}

In ${ }^{5}$ Proposed a Model for the Successful Application of Knowledge Management in 15 Saudi Universities. It was applied to a random stratified sample of (338) individuals. It is based on the impact of infrastructure implications on the application of knowledge management processes and on the impact of motivation on knowledge management practices. Tools were used to measure questionnaires through the web. The most important results of this study were the following: (a) a moral significance among the factors (knowledge stimulation (motivation), knowledge technology formation (configuration), management of individual attitudes towards knowledge, creation of knowledge culture, knowledge leadership formation) in the dependent variable (actual practice of knowledge management in Saudi universities). It stressed on hypothesis model that motivation has an impact on the actual practice of knowledge management.
$\mathrm{In}^{2}$ studied the impact of strategic leadership on knowledge sharing as a case study for a set of hotels. The study was applied to a simple random sample of (341) hotel staff in Algeria. According to them, the behavior and strategy of knowledge sharing is explained by strategic leadership practices in their dimensions, practices associated with organizational culture, and strategic leadership practices have an indirect impact on both the behavior and strategy of knowledge sharing through internal coordination (incentive activities).

$\mathrm{In}^{6}$ provided a model for Knowledge Sharing (KS) in research centers that can facilitate the employee's Knowledge Sharing Behavior (KSB). The structural equation modeling (SEM) was used to assess the measurement model and to test the research hypotheses. The study was applied to a sample consisted of (317) complete questionnaires from research centers in Iran republic. The findings show that intrinsic and extrinsic motivational factors and intention to methods of KS play an important role in KSB. In other words, simultaneous supply of motivational factors and KS methods interesting for employees lead to their KSB. The SEM confirmed the research model and showed a good fit of it. The implication emanating from this study is that the employees' KSB in RCs as a significant part depends on simultaneous supplying of motivational factors (especially intrinsic motivational factors) and methods of KS that are interesting for employees.

$\mathrm{In}^{\mathrm{T}}$ identified the impact of knowledge cultivation and investment in human capital within organizations in achieving an effective face of knowledge monopoly. The study was applied to a sample consisted of (119) members of The Arab Board of Health Specializations. Tools were used for measurement: Structural Equation Modeling (SEM). One of the most important findings of this study was the existence of correlation and the impact of knowledge cultivation which is the transformation of knowledge and knowledge sharing in the face of the monopoly of knowledge directly or through indicators of investment in intellectual capital indirectly. It also showed the impact of the motivation factor to share knowledge in the face of knowledge monopoly.

$\mathrm{In}^{8}$ studied the role of Moa Framework on Knowledge Sharing and Tourist Behavioral Intention. This study evaluated the significance of motivation, opportunity, ability (MOA model) on knowledge sharing, destination 
image and behavioral intention. The moderating role of openness to experience is also examined. The study was applied to a sample consisted of (262) valid responses. The results suggest that MOA significantly influence knowledge sharing. Knowledge sharing has a positive effect on destination image, and destination image has a positive relationship with behavioral intention. Moreover, openness to experience is regarded as a positive moderator that can strengthen the influence of MOA on knowledge sharing.

\section{Problem of Study}

Since both genders are working in educational field of government / public sector and availability of accumulated knowledge among old employees, female employee notes that there is a confusion between the role of the organization as to the so-called organizational knowledge and the knowledge sharing obtained by the experts from old and new employees; and there are different methods of knowledge sharing that are not well implemented. On this context, the researcher attempted to address the methods used and to identify the preferred methods of knowledge sharing in the Saudi government / public sector.

As a result of the nature of this study in terms of the quality of its variables and sources of information, it is considered one as of survey descriptive studies, which is the type of research that is conducted by questioning all members of the research population or a large sample of them in order to describe the phenomenon studied in terms of nature and degree of existence and the conclusion of reasons. Specifically, the study will use the survey approach to collect data among individuals in the society through questionnaire.

\section{Method of the Study}

The study population consists of all employees in the Ministry of Education. As a result of the multiplicity of education sectors, a random sample of employees in Saudi universities (King Abdulaziz University, King Saud University, North Jeddah University, Bisha University) was selected where the number of individuals of the sample reached (400) distributed equally between universities.

\subsection{Tools of Study}

Questionnaire was used as a main tool for the study and consisted of two axes; the first axis consists of (21) phrases / statements that measure the methods of knowledge sharing used by employees in their work environment. The second axis consists of (18) phrases / statements that look for the most important methods of knowledge sharing to share their knowledge with others.

\subsection{The limits of the Study}

The study dealt with methods of sharing knowledge used by employees as well as the methods they prefer. It was conducted in 2018 at Saudi universities (King Abdulaziz University, King Saud University, North Jeddah University, Bisha University)

\section{Results}

The result of the first questionwhat are the methods of sharing knowledge used by employees of Saudi Arabia' government / public sectoras shows in table 1 :

It is clear from the above table that the elements (items) of knowledge sharing methods axis used among employees of Saudi Arabia's public sector were as follows in descending order according to the average opinion of the study sample and comparing the results in the table of approval limits:

The first of these methods (Employees in our organization have to help each other if they need one another). The opinion was strongly agreeing with average of (4.38) namely employees use this method at $84.50 \%$. The second method was (The highly-experienced employees should train the least experienced ones to improve their performance). The opinion was strongly agreeing with average of (4.29) namely employees use this method at $82.25 \%$. The third method was (The most experienced employees train (practically) the less well-known and experienced employees to help them manage the business in the future). The opinion was strongly agreeing with average of (4.28) namely employees use this method at $82.0 \%$.

The result of the second question what are the methods of sharing knowledge with others preferred by employees of Saudi Arabia' government / public sector as shown in Table 2. 
Table 1. Results of the first question

\begin{tabular}{|c|c|c|c|c|c|c|c|c|c|c|c|}
\hline \multirow{2}{*}{\multicolumn{2}{|c|}{$\begin{array}{l}\text { Statement (Phrase) } \\
\text { Strongly Disagree }\end{array}$}} & \multicolumn{5}{|c|}{ Degree of Approval } & \multirow{2}{*}{$\begin{array}{l}\text { Sample } \\
\text { Average } \\
\text { Views }\end{array}$} & \multirow[b]{2}{*}{$\begin{array}{l}\text { Standard } \\
\text { Deviation }\end{array}$} & \multirow{2}{*}{$\begin{array}{c}\text { Weight } \\
\text { Percentage } \\
\%\end{array}$} & \multirow[b]{2}{*}{$\begin{array}{l}\text { Degree of } \\
\text { Approval }\end{array}$} & \multirow[b]{2}{*}{$\begin{array}{l}\text { Order of } \\
\text { Methods }\end{array}$} \\
\hline & & Disagree & $\begin{array}{l}\text { Some } \\
\text { what }\end{array}$ & Agree & Strongly & & & & & & \\
\hline \multirow{2}{*}{$\begin{array}{l}\text { 1. We use the } \\
\text { traditional } \\
\text { (paper) } \\
\text { method to } \\
\text { document our } \\
\text { knowledge }\end{array}$} & $\mathrm{T}$ & 7 & 48 & 60 & 150 & 105 & \multirow[b]{2}{*}{3.81} & \multirow[b]{2}{*}{0.84} & \multirow[b]{2}{*}{70.25} & \multirow[b]{2}{*}{ Agree } & \multirow[b]{2}{*}{19} \\
\hline & $\%$ & 1.9 & 13.0 & 16.2 & 40.5 & 28.4 & & & & & \\
\hline \multirow{2}{*}{$\begin{array}{l}\text { 2. We use } \\
\text { computerized } \\
\text { databases } \\
\text { to store and } \\
\text { document } \\
\text { knowledge }\end{array}$} & $\mathrm{T}$ & 1 & 13 & 42 & 165 & 149 & \multirow[b]{2}{*}{4.21} & \multirow[b]{2}{*}{0.79} & \multirow[b]{2}{*}{80.25} & \multirow[b]{2}{*}{ Agree } & \multirow[b]{2}{*}{6} \\
\hline & $\%$ & 0.3 & 3.5 & 11.4 & 44.6 & 40.3 & & & & & \\
\hline \multirow{2}{*}{$\begin{array}{l}\text { 3. Employees } \\
\text { in our } \\
\text { organization } \\
\text { have to help } \\
\text { each other if } \\
\text { they need one } \\
\text { another }\end{array}$} & $\mathrm{T}$ & - & 4 & 32 & 152 & 182 & \multirow[b]{2}{*}{4.38} & \multirow[b]{2}{*}{0.69} & \multirow[b]{2}{*}{84.50} & \multirow[b]{2}{*}{$\begin{array}{l}\text { Strongly } \\
\text { Agree }\end{array}$} & \multirow[b]{2}{*}{1} \\
\hline & $\%$ & - & 1.1 & 8.6 & 41.1 & 49.2 & & & & & \\
\hline \multirow{2}{*}{$\begin{array}{l}\text { 4. Employees } \\
\text { discuss the } \\
\text { work they } \\
\text { do and the } \\
\text { resulting } \\
\text { results with } \\
\text { each other }\end{array}$} & $\mathrm{T}$ & 1 & 3 & 35 & 187 & 144 & \multirow[b]{2}{*}{4.27} & \multirow[b]{2}{*}{0.68} & \multirow[b]{2}{*}{81.75} & \multirow[b]{2}{*}{$\begin{array}{l}\text { Strongly } \\
\text { Agree }\end{array}$} & \multirow[b]{2}{*}{4} \\
\hline & $\%$ & 0.3 & 0.8 & 9.5 & 50.5 & 38.9 & & & & & \\
\hline \multirow{2}{*}{$\begin{array}{l}5 . \text { We use } \\
\text { storytelling for } \\
\text { the purpose } \\
\text { of knowledge } \\
\text { sharing } \\
\text { within the } \\
\text { organization }\end{array}$} & $\mathrm{T}$ & 6 & 27 & 86 & 151 & 100 & \multirow[b]{2}{*}{3.84} & \multirow[b]{2}{*}{0.95} & \multirow[b]{2}{*}{71.00} & \multirow[b]{2}{*}{ Agree } & \\
\hline & $\%$ & 1.6 & 7.3 & 23.2 & 40.8 & 27.0 & & & & & 17 \\
\hline $\begin{array}{l}\text { 6. the most } \\
\text { experienced }\end{array}$ & $\mathrm{T}$ & 2 & 14 & 63 & 165 & 126 & & & & & \\
\hline $\begin{array}{l}\text { teach } \\
\text { (theoretically) } \\
\text { the less well- } \\
\text { known and } \\
\text { experienced } \\
\text { employees } \\
\text { to help them } \\
\text { manage the } \\
\text { business in the } \\
\text { future }\end{array}$ & $\%$ & 0.5 & 3.8 & 17.0 & 44.6 & 34.1 & 4.08 & 0.84 & 77.00 & Agree & 11 \\
\hline
\end{tabular}




\begin{tabular}{|c|c|c|c|c|c|c|c|c|c|c|c|}
\hline \multirow{2}{*}{$\begin{array}{l}\text { 7. the most experienced employees train } \\
\text { (practically) the less well-known and } \\
\text { experienced employees to help them manage } \\
\text { the business in the future }\end{array}$} & $\mathrm{T}$ & - & 9 & 40 & 159 & 162 & \multirow{2}{*}{4.28} & \multirow{2}{*}{0.75} & \multirow{2}{*}{82.00} & \multirow{2}{*}{$\begin{array}{l}\text { Strongly } \\
\text { Agree }\end{array}$} & \multirow{2}{*}{3} \\
\hline & $\%$ & - & 2.4 & 10.8 & 43.0 & 43.8 & & & & & \\
\hline \multirow{2}{*}{$\begin{array}{l}\text { 8. Participants participate in interviews and } \\
\text { dialogues dedicated to exchanging views and } \\
\text { experiences }\end{array}$} & $\mathrm{T}$ & - & 5 & 60 & 175 & 130 & \multirow{2}{*}{4.16} & \multirow{2}{*}{0.73} & \multirow{2}{*}{79.00} & \multirow{2}{*}{ Agree } & \multirow{2}{*}{8} \\
\hline & $\%$ & & 1.4 & 16.2 & 47.3 & 35.1 & & & & & \\
\hline \multirow{2}{*}{$\begin{array}{l}\text { 9. Everyone should participate in discussing } \\
\text { the problems of work and finding solutions to } \\
\text { them }\end{array}$} & $\mathrm{T}$ & 1 & 5 & 53 & 151 & 160 & \multirow{2}{*}{4.25} & \multirow{2}{*}{0.76} & \multirow{2}{*}{81.25} & \multirow{2}{*}{$\begin{array}{l}\text { Strongly } \\
\text { Agree }\end{array}$} & \multirow{2}{*}{5} \\
\hline & $\%$ & 0.3 & 1.4 & 14.3 & 40.8 & 43.2 & & & & & \\
\hline \multirow{2}{*}{$\begin{array}{l}\text { 10. The highly-experienced employees should } \\
\text { train the least experienced ones to improve } \\
\text { their performance }\end{array}$} & $\mathrm{T}$ & - & 5 & 46 & 155 & 164 & \multirow{2}{*}{4.29} & \multirow{2}{*}{0.73} & \multirow{2}{*}{82.25} & \multirow{2}{*}{$\begin{array}{l}\text { Strongly } \\
\text { Agree }\end{array}$} & \multirow{2}{*}{2} \\
\hline & $\%$ & - & 1.4 & 12.4 & 41.9 & 44.3 & & & & & \\
\hline \multirow{2}{*}{$\begin{array}{l}\text { 11. Officials prefer to do works collectively } \\
\text { whenever possible }\end{array}$} & $\mathrm{T}$ & 1 & 6 & 71 & 156 & 136 & \multirow{2}{*}{4.14} & \multirow{2}{*}{0.79} & \multirow{2}{*}{78.50} & \multirow{2}{*}{ Agree } & \multirow{2}{*}{9} \\
\hline & $\%$ & 0.3 & 1.6 & 19.2 & 42.2 & 36.8 & & & & & \\
\hline \multirow{2}{*}{$\begin{array}{l}\text { 12. Managers frequently alternate roles } \\
\text { between us }\end{array}$} & $\mathrm{T}$ & 5 & 19 & 72 & 149 & 125 & (مח & 000 & 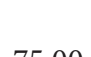 & $A \sim$ & \\
\hline & $\%$ & 1.4 & 5.1 & 19.5 & 40.3 & 33.8 & & & & & \\
\hline 13 Officials alwavs uroe us to narticinate in & $\mathrm{T}$ & - & 15 & 71 & 171 & 113 & & & & & \\
\hline various discussions & $\%$ & - & 4.1 & 19.2 & 46.2 & 30.5 & & & & & \\
\hline $\begin{array}{l}\text { 14. We must participate in various conferences } \\
\text { held by the establishment / institution / }\end{array}$ & $\mathrm{T}$ & 4 & 7 & 55 & 184 & 120 & 4.11 & 0.79 & 77.75 & Agree & 10 \\
\hline organization & $\%$ & 1.1 & 1.9 & 14.9 & 49.7 & 32.4 & & & & & \\
\hline 15. The organization conducts workshops for & $\mathrm{T}$ & 4 & 13 & 73 & 169 & 111 & 4.00 & 0.85 & 75.00 & Agree & 14 \\
\hline & $\%$ & 1.1 & 3.5 & 19.7 & 45.7 & 30.0 & & & & & \\
\hline $\begin{array}{l}\text { 16. Employees use modern means to } \\
\text { communicate with colleagues / workmates }\end{array}$ & $\mathrm{T}$ & - & 5 & 63 & 169 & 133 & 4.16 & 0.74 & 79.00 & Agree & 7 \\
\hline $\begin{array}{l}\text { such as e-mail, chat room, social media and } \\
\text { others }\end{array}$ & $\%$ & - & 1.4 & 17.0 & 45.7 & 35.9 & & & & & \\
\hline 17. There is a knowledge café where & $\mathrm{T}$ & 20 & 49 & 74 & 126 & 101 & 3.65 & 0.86 & 66.25 & Agree & 21 \\
\hline & $\%$ & 5.4 & 13.2 & 20.0 & 34.1 & 27.3 & & & & & \\
\hline & $\mathrm{T}$ & 22 & 40 & 67 & 135 & 106 & & & & & \\
\hline $\begin{array}{l}\text { 18. There is a social networking program blog } \\
\text { in the organization where we share knowledge }\end{array}$ & $\%$ & 5.9 & 10.8 & 18.1 & 36.5 & 28.6 & 3.71 & 0.76 & 67.75 & Agree & 20 \\
\hline
\end{tabular}




\begin{tabular}{|c|c|c|c|c|c|c|c|c|c|c|c|}
\hline \multirow{2}{*}{$\begin{array}{l}\text { 19. There are groups of interest and active } \\
\text { practice in the Organization through which we } \\
\text { share knowledge }\end{array}$} & $\mathrm{T}$ & 15 & 29 & 74 & 140 & 112 & \multirow{2}{*}{3.82} & \multirow{2}{*}{0.77} & \multirow{2}{*}{70.50} & \multirow{2}{*}{ Agree } & \multirow{2}{*}{18} \\
\hline & $\%$ & 4.1 & 7.8 & 20.0 & 37.8 & 30.3 & & & & & \\
\hline \multirow{2}{*}{$\begin{array}{l}\text { 20. The e-organization's portal supports } \\
\text { knowledge sharing and allows knowledge to be } \\
\text { received and disseminated }\end{array}$} & $\mathrm{T}$ & 11 & 20 & 52 & 17. & 117 & \multirow{2}{*}{3.98} & \multirow{2}{*}{0.97} & \multirow{2}{*}{74.50} & \multirow{2}{*}{ Agree } & \multirow{2}{*}{16} \\
\hline & $\%$ & 3.0 & 5.4 & 5.4 & 45.9 & 31.6 & & & & & \\
\hline \multirow{2}{*}{$\begin{array}{l}\text { 21. There is an official group of members in a } \\
\text { social network platform }\end{array}$} & $\mathrm{T}$ & 12 & 21 & 50 & 143 & 144 & \multirow{2}{*}{4.04} & \multirow{2}{*}{0.82} & \multirow{2}{*}{76.00} & \multirow{2}{*}{ Agree } & \multirow{2}{*}{12} \\
\hline & $\%$ & 3.2 & 5.7 & 13.5 & 38.6 & 38.9 & & & & & \\
\hline \multirow{2}{*}{ Axis Total Average } & $\mathrm{T}$ & 5 & 17 & 59 & 158 & 131 & \multirow{2}{*}{4.07} & \multirow{2}{*}{0.687} & \multirow{2}{*}{76.75} & & \\
\hline & $\%$ & 1.4 & 4.6 & 15.9 & 42.7 & 35.4 & & & & & \\
\hline
\end{tabular}

Table 2. Results of the second question

\begin{tabular}{|c|c|c|c|c|c|c|c|c|c|c|c|}
\hline \multirow{2}{*}{\multicolumn{2}{|c|}{$\begin{array}{c}\text { Statement } \\
\text { (Phrase) } \\
\text { Strongly Disagree }\end{array}$}} & \multicolumn{5}{|c|}{ Degree of Approval } & \multirow[b]{2}{*}{$\begin{array}{c}\text { Sample } \\
\text { Average } \\
\text { Views }\end{array}$} & \multirow[b]{2}{*}{$\begin{array}{l}\text { Standard } \\
\text { Deviation }\end{array}$} & \multirow[b]{2}{*}{$\begin{array}{c}\text { Weight } \\
\text { Percentage } \\
\%\end{array}$} & \multirow[b]{2}{*}{$\begin{array}{l}\text { Degree of } \\
\text { Approval }\end{array}$} & \multirow[b]{2}{*}{$\begin{array}{l}\text { Order of } \\
\text { Methods }\end{array}$} \\
\hline & & Disagree & $\begin{array}{l}\text { Some } \\
\text { what } \\
\text { True }\end{array}$ & Agree & $\begin{array}{c}\text { Strongly } \\
\text { Agree }\end{array}$ & & & & & & \\
\hline \multirow{2}{*}{$\begin{array}{l}\text { 1. Use the } \\
\text { traditional } \\
\text { (papers) } \\
\text { method to } \\
\text { document my } \\
\text { knowledge }\end{array}$} & $\mathrm{T}$ & 17 & 41 & 83 & 149 & 80 & \multirow[b]{2}{*}{3.63} & \multirow[b]{2}{*}{0.78} & \multirow[b]{2}{*}{65.75} & \multirow[b]{2}{*}{ Agree } & \multirow[b]{2}{*}{18} \\
\hline & $\%$ & 4.6 & 11.1 & 22.4 & 40.3 & 21.6 & & & & & \\
\hline \multirow{2}{*}{$\begin{array}{l}\text { 2. Use a } \\
\text { database to } \\
\text { record and } \\
\text { document } \\
\text { knowledge }\end{array}$} & $\mathrm{T}$ & 1 & 6 & 31 & 186 & 146 & \multirow[b]{2}{*}{4.27} & \multirow[b]{2}{*}{0.70} & \multirow[b]{2}{*}{81.75} & \multirow[b]{2}{*}{$\begin{array}{c}\text { Strongly } \\
\text { Agree }\end{array}$} & \multirow[b]{2}{*}{10} \\
\hline & $\%$ & 0.3 & 1.6 & 8.4 & 50.3 & 39.5 & & & & & \\
\hline \multirow{2}{*}{$\begin{array}{l}\text { 3. Help my } \\
\text { colleagues if } \\
\text { they ask for } \\
\text { help }\end{array}$} & $\mathrm{T}$ & - & 2 & 19 & 171 & 178 & \multirow{2}{*}{4.42} & \multirow{2}{*}{0.61} & \multirow{2}{*}{85.50} & \multirow{2}{*}{$\begin{array}{c}\text { Strongly } \\
\text { Agree }\end{array}$} & \multirow{2}{*}{1} \\
\hline & $\%$ & - & 0.5 & 5.1 & 46.2 & 48.1 & & & & & \\
\hline \multirow{2}{*}{$\begin{array}{l}\text { 4. Discuss } \\
\text { colleagues } \\
\text { about what we } \\
\text { do and what } \\
\text { results }\end{array}$} & $\mathrm{T}$ & - & 4 & 30 & 167 & 169 & \multirow[b]{2}{*}{4.35} & \multirow[b]{2}{*}{0.67} & \multirow[b]{2}{*}{83.75} & \multirow[b]{2}{*}{$\begin{array}{c}\text { Strongly } \\
\text { Agree }\end{array}$} & \multirow[b]{2}{*}{7} \\
\hline & $\%$ & - & 1.1 & 8.1 & 45.1 & 45.7 & & & & & \\
\hline
\end{tabular}




\begin{tabular}{|c|c|c|c|c|c|c|c|c|c|c|c|}
\hline \multirow{2}{*}{$\begin{array}{l}\text { 5. Giving stories as an effective } \\
\text { method to convey my knowledge } \\
\text { to others }\end{array}$} & $\mathrm{T}$ & 5 & 15 & 64 & 165 & 121 & \multirow{2}{*}{4.03} & \multirow{2}{*}{0.88} & \multirow{2}{*}{75.75} & \multirow{2}{*}{ Agree } & \multirow{2}{*}{16} \\
\hline & $\%$ & 1.4 & 4.1 & 17.3 & 44.6 & 32.7 & & & & & \\
\hline \multirow{2}{*}{$\begin{array}{l}\text { 6. Teach (theoretically) employees } \\
\text { with less knowledge and } \\
\text { experience to help them perform } \\
\text { works in the future }\end{array}$} & $\mathrm{T}$ & 3 & 11 & 40 & 194 & 122 & \multirow{2}{*}{4.14} & \multirow[b]{2}{*}{0.78} & \multirow[b]{2}{*}{78.50} & \multirow[b]{2}{*}{ Agree } & \multirow[b]{2}{*}{14} \\
\hline & $\%$ & 0.8 & 3.0 & 10.8 & 52.4 & 33.0 & & & & & \\
\hline \multirow{2}{*}{$\begin{array}{l}\text { 7. Encourage employees with less } \\
\text { knowledge and experience to } \\
\text { accept their assistance and train } \\
\text { them to perform works in the } \\
\text { future }\end{array}$} & $\mathrm{T}$ & - & - & 40 & 177 & 153 & \multirow{2}{*}{4.31} & \multirow{2}{*}{0.65} & \multirow{2}{*}{82.75} & \multirow{2}{*}{$\begin{array}{l}\text { Strongly } \\
\text { Agree }\end{array}$} & \multirow{2}{*}{8} \\
\hline & $\%$ & - & - & 10.8 & 47.8 & 41.4 & & & & & \\
\hline \multirow{2}{*}{$\begin{array}{l}\text { 8. Participation in interviews } \\
\text { and dialogues dedicated to } \\
\text { exchanging views, experiences } \\
\text { and work meetings }\end{array}$} & $\mathrm{T}$ & - & 3 & 40 & 193 & 134 & \multirow{2}{*}{4.24} & \multirow{2}{*}{0.66} & \multirow{2}{*}{81.00} & \multirow{2}{*}{ Agree } & \multirow{2}{*}{12} \\
\hline & $\%$ & - & 0.8 & 10.8 & 52.2 & 36.2 & & & & & \\
\hline \multirow{2}{*}{$\begin{array}{l}\text { 9. Peer participation in discussion } \\
\text { of problems and finding solutions }\end{array}$} & $\mathrm{T}$ & - & - & 20 & 182 & 168 & \multirow{2}{*}{4.40} & \multirow{2}{*}{0.59} & \multirow{2}{*}{85.00} & \multirow{2}{*}{$\begin{array}{l}\text { Strongly } \\
\text { Agree }\end{array}$} & \multirow{2}{*}{2} \\
\hline & $\%$ & - & - & 5.4 & 49.2 & 45.4 & & & & & \\
\hline \multirow{2}{*}{$\begin{array}{l}\text { 10. The desire to train my } \\
\text { colleagues / workmates to } \\
\text { upgrade their performance }\end{array}$} & $\mathrm{T}$ & - & 2 & 26 & 172 & 170 & \multirow{2}{*}{4.38} & & & & \\
\hline & $\%$ & - & 0.5 & 7.0 & 46.5 & 45.9 & & & & Agree & \\
\hline 11. Participate in workgroups & $\mathrm{T}$ & - & 1 & 33 & 162 & 174 & & & & Stronoly & \\
\hline individually & $\%$ & - & 0.3 & 8.9 & 43.8 & 47.0 & & & & Agree & \\
\hline $\begin{array}{l}\text { 12. Mobility between different } \\
\text { jobs and work experience in more }\end{array}$ & $\mathrm{T}$ & 1 & 12 & 44 & 143 & 170 & 4.27 & 0.81 & 81.75 & Strongly & 11 \\
\hline than one department & $\%$ & 0.3 & 3.2 & 11.9 & 38.6 & 45.9 & & & & & \\
\hline 13. Communicate and participate & $\mathrm{T}$ & 2 & 6 & 45 & 176 & 141 & & & & & \\
\hline their subject & $\%$ & 0.5 & 1.6 & 12.2 & 47.6 & 38.1 & & & & & \\
\hline 14. Participation in various & $\mathrm{T}$ & 2 & 2 & 24 & 165 & 177 & & & & Strongly & \\
\hline by the organization & $\%$ & 5. & 0.5 & 6.5 & 44.6 & 47.8 & & & & Agree & \\
\hline $\begin{array}{l}\text { 15. Use modern means to } \\
\text { communicate with colleagues }\end{array}$ & $\mathrm{T}$ & 2 & 1 & 28 & 158 & 181 & 20 & $0<0$ & 047 & Strongly & 2 \\
\hline $\begin{array}{l}\text { such as e-mail, chat rooms, social } \\
\text { media and others }\end{array}$ & $\%$ & 0.5 & 0.3 & 7.6 & 42.7 & 48.9 & & & & Agree & \\
\hline
\end{tabular}




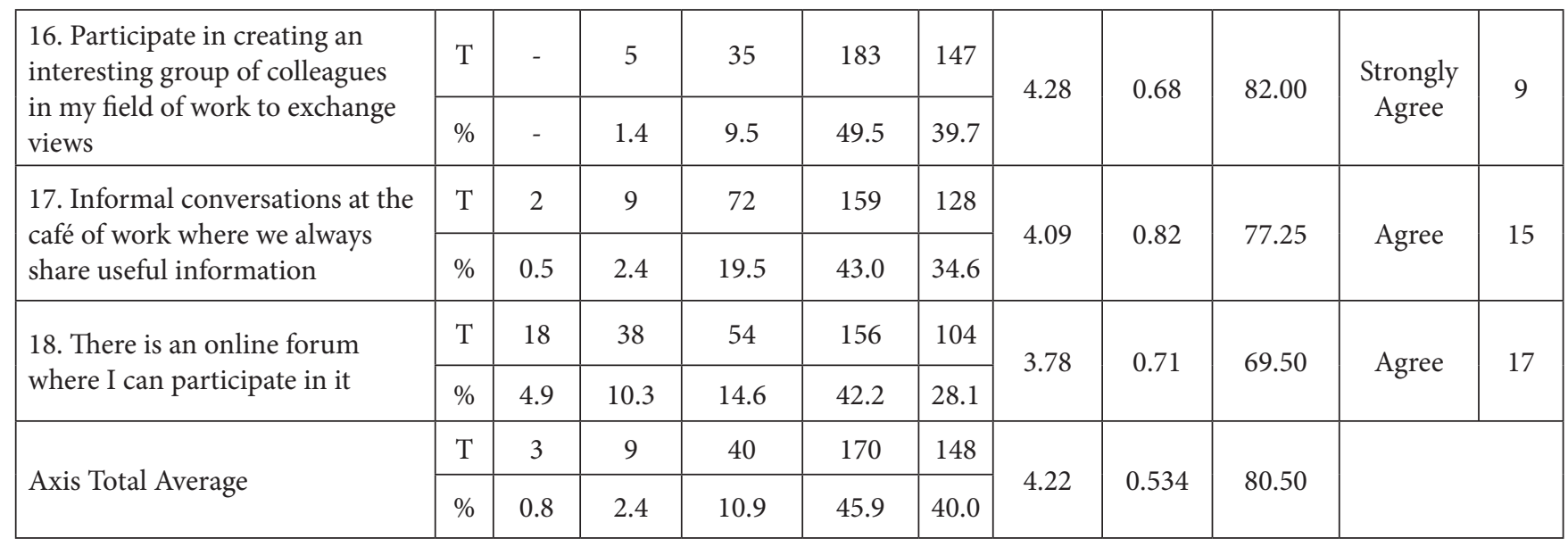

It is clear from the above table that the elements (items) of knowledge sharing methods axis preferred among employees of Saudi Arabia's public sector were as follows in descending order according to the average opinion of the study sample and comparing the results in the table of approval limits:

The first of these methods was (Help my colleagues if they ask for help). The opinion was strongly agreeing with average of (4.42) meaning that employees are using this method as a preferred method of sharing at $85.50 \%$. The standard deviation was 0.61 , which is a small value. This indicates that there is no divergence in the views (opinions) of the study sample towards this method.

Then, the second method which was (Peer participation in discussion of problems and finding solutions) and the opinion was strongly agree with average of (4.40) meaning that employees are preferring this method as a preferred one to share knowledge with other colleagues / workmates at $85.00 \%$.

Then, the third method which was (Use modern means to communicate with colleagues such as e-mail, chat rooms, social media and others) and the opinion was strongly agree with average of (4.39) meaning that employees are preferring this method as a preferred one to them at $84.75 \%$.

Then the sequence of the other methods according to their order and preference among the employees as mentioned in the table (Methods Order Column) until we reach the last of these methods which is (Use the traditional (papers) method to document my knowledge) and the opinion was Agree with average of (3.63). This method received the approval of the sample as a preferred method of sharing knowledge with others.

\section{Results and Discussion}

$\operatorname{In}^{9}$ noted that one of the most important factors influencing the sharing of knowledge (individual dimension) such as awareness, trust, personality, job satisfaction and (institutional dimension), which was set in administrative support and reward.

$\operatorname{In}^{10}$ determined that the most important key to knowledge sharing is trust / confidence i.e. trust between individuals that does not harm them. The results of the study were consistent to some extent with most studies such as the study conducted by (Al-Zanibat, 2011) and also the study conducted by (Aktay, 2014) ${ }^{1}$. The results of the study were about the methods used by the sample to share knowledge. Also, it concluded with the following (Provide assistance in case of need, training by experienced staff, hands-on training, participation in work discussions, use of databases and use of modern communication methods).

Regarding the preferred methods for knowledge sharing, the results were as follows: (help colleagues / workmates in case of need, participate in work discussions to find solutions, use new methods of communication with colleagues / workmates, education and training, moral encouragement, formation of interest groups, use database to document knowledge, use traditional methods to document knowledge) as in Table 3.

By analyzing the most important factors, it appears that there is no difference between the available methods and methods preferred by employees to share knowledge. The logical explanation may be that there is no difference between what employees prefer and what exists as a result of either employees not recognizing the principles 
Table 3. Methods of knowledge sharing available in the organization and the preferred methods among employees

\begin{tabular}{|l|l|l|}
\hline SN & $\begin{array}{l}\text { Methods of knowledge sharing available in the } \\
\text { organization }\end{array}$ & $\begin{array}{l}\text { Methods of knowledge sharing preferred by } \\
\text { employees }\end{array}$ \\
\hline 1 & Provide assistance in case of need & Help colleagues / workmates in case of need \\
\hline 2 & Training by experienced staff, hands-on training & Education \& training \\
\hline 3 & Participation in work discussions & Participate in work discussions to find solutions \\
\hline 4 & Use of databases & $\begin{array}{l}\text { Use database to document knowledge, use traditional } \\
\text { methods to document knowledge }\end{array}$ \\
\hline 5 & Use of modern communication methods & $\begin{array}{l}\text { Use new methods of communication with colleagues / } \\
\text { workmates }\end{array}$ \\
\hline
\end{tabular}

of knowledge management and its importance in their knowledge formation or the presence of sharing methods, but at the same time it is not so effective to make a difference and a clear impact in the organization as a result of the absence of supportive organizational culture or other causes (e.g., training, moral encouragement and the formation of interest groups).

\section{Conclusions and Recommendation}

The study recommends activating the methods of knowledge sharing within government/public sector and supporting them in terms of developing a system of incentives that takes into account the sharing of knowledge as well as the dissemination of a culture of organizational support for knowledge sharing. The also recommends studies on the factors that encourage the knowledge sharing among Saudi Arabia's public sector employees.

\section{Acknowledgement}

This paper has been presented and discussed during the International Conference on Communication, Management and Information Technology- ICCMIT 2019, Vienna, Austria.

\section{References}

1. Farkas F. The role of leadership in knowledge management, and knowledge transfer. Knowledge Transfer, Small and
Medium Sized Enterprises and Regional, Development in Hungary; 2003.

2. Jawhara A. The impact of strategic leadership on knowledge sharing. PhD Thesis, Presented to the University of Mohamed Khader- Algeria; 2014.

3. Abdul-Sattar, A-A, Kandilji, and Omari. Introduction to Knowledge Management, Dar Al-Masar for Publishing and Distribution, Amman; 1433.

4. Al-Kubaisi S. Knowledge management. Cairo, Arab Organization for Administrative Development; 2015.

5. Al-Znibat M. Testing a proposed model for the successful application of knowledge management in Saudi Universities: Towards an effective knowledge management strategy. The Arab Journal of Management Studies, Amman Jordan; 2011.

6. V-Akhavan P, Rahimi A, Mehralian G. Developing a model for knowledge sharing in research centers, The Journal of Information and Knowledge Management Systems. 2013; 43(3):357-93. https://doi.org/10.1108/VINE-06-2012-0020

7. Hakim $\mathrm{M}$ et al. Knowledge cultivation and investment in human capital and their role in the face of knowledge monopoly: An applied study on a sample of students of the Arab board (PhD). Journal of Administrative Sciences University of Mustansiriya, Baghdad, Iraq; 2013.

8. A-Wu WY, Chen SH, Lu HY. The role of moa framework on knowledge sharing and tourist behavioral intention. In Southwest Decision Sciences Institute Conference, Houston, TX; 2011.

9. Kogut B, Zander U. Knowledge of the firm, combinative capabilities, and the replication of technology. Organization Science. 1992; 3(3):383-97. https://doi.org/10.1287/ orsc.3.3.383

10. Scarbrough H, Swan J. Knowledge communities and innovation. Husyman M, Van Baalen P, editors. Trends in Communication; Special issues on Communities of Practice. Amsterdam: Boom; 2001. 